\title{
Avian influenza ( H5 subtype) antibodies in village chickens in four local government areas of Kaduna state, Nigeria
}

\author{
Victor T. Gugong ${ }^{1}$ I kwe Ajogi², Kabir Juniadu², Emmanuel C. Okolocha², Emmanuel O. Ngbede ${ }^{3}$,
} Sunday E. Hambolu', Nanven A. Maurice ${ }^{4}$

1. Nuhu Bamali Polytechnic, School of Agricultural Technology, Samaru-Kataf, Kaduna State, Nigeria. 2. Department of Veterinary Public Health and Preventive Medicine, Ahmadu Bello University, Zaria. P.M.B. 1045 Samaru Zaria Kaduna State, Nigeria. 3. Department of Veterinary Microbiology, Ahmadu Bello University Zaria. P.M.B. 1045 Samaru Zaria Kaduna State, Nigeria. 4. National Veterinary Research Institute (NVRI), South-South Zonal Laboratory Calabar, Cross River State, Nigeria.

Corresponding author: Victor T. Gugong, Email address: titagongs@yahoo.com, Tel: +2347039663197 Received: 24-05-2012, Accepted: 03-06-2012, Published Online: 29-10-2012 doi: 10.5455/vetworld.2012.713-717

\begin{abstract}
Aim: Biosecurity measures are rarely implemented in traditional farming systems especially in the villages. Given the importance of the village chickens as a source of income for rural families and its public health concern due to the frequent contact that exist between these birds and humans a study was conducted to assess the presence of antibodies to the H5 avian influenza virus subtype in village chickens in some Local Government Areas (LGAs) in Kaduna State.

Materials and Methods: A total of 480 sera samples were obtained from apparently healthy local chickens in five LGAs where the avian influenza outbreak has not been reported. The sera were subjected to the Haemagglutination inhibition (HI) test using the $\mathrm{H} 5 \mathrm{~N} 2$ avian influenza antigen.

Results: An overall prevalence of $2.9 \%$ with an individual seroprevalence of $10 \%, 0.8 \%, 4.1 \%$ and $3.3 \%$ in Jaba, Jemma'a, Kaura and Zango Kataf local government areas respectively. There was no association between presence of pigs and detection of avian influenza antibodies, $\mathrm{p}=0.8723$, OR 0.9153 (95\% CI: 0.3108-2.695), but there was an association between presence of water birds (Gesse and Ducks) and detection of avian influenza antibodies, p=0.0203, OR 3.488 (95\% CI: 1.146-10.61).

Conclusions: This result highlights the important role apparently healthy village chickens may play in virus perpetuation (reservoir) and in the spread of avian influenza to other animals and humans. An enhanced and sustained virological surveillance for the virus in village chickens was recommended.
\end{abstract}

Keywords: antibodies, avian influenza, Kaduna State, Nigeria, village chickens

To cite this article: Gugong VT, Ajogi I, Juniadu K, Okolocha EC, Ngbede EO, Hambolu SE, Maurice NA (2012) Avian influenza (H5 subtype) antibodies in village chickens in four local government areas of Kaduna state, Nigeria, Vet World, 5(12): 713-717, doi: 10.5455/vetworld.2012.713-717

\section{I ntroduction}

In Nigeria, about $60 \%$ of the poultry population are kept under the free rang/scavenging system of production [1]. Biosecurity measures are rarely implemented in the rearing of the village chickens especially in the villages. The chickens therefore, roam freely from one property to another making them more vulnerable to infection. When infected they may become a perpetual nucleus of virus circulation and become a potential virus source [2].

Local poultry production system has been shown to be an important source of spread and persistence of highly pathogenic avian influenza (HPAI) H5N1 [3], yet epidemiological surveys of avian influenza infection rarely focus on the local poultry (free range) system. They are considered to have little influence on the emergence, re-emergence and spread of AI virus. Thus this study was designed to determine the presence of $\mathrm{AI}$ antibodies in village chickens with a view to determining their role in the epidemiology and spread of the disease.

\section{Materials and Methods}

The first outbreak of AI in Nigeria was occurred in Kaduna State [4]. The disease has since spread to 25 out of the 36 states including the Federal Capital territory (FCT) [5]. The disease was not reported in Kaura, Jemma'a, Jaba and Zangon Kataf local government areas throughout the period of the outbreak, even though, it has live bird markets and access roads through which poultry and poultry products are transported during this period from Abuja 
Avian influenza (H5 subtype) antibodies in village chickens in four local government areas of Kaduna state

Table-1. Distribution of samples across the four local government areas and the prevalence of village chickens positive for antibodies to the $\mathrm{H} 5$ avian influenza in these areas.

\begin{tabular}{lccccc}
\hline Variables & J aba & J emma'a & Kaura & Zango Kataf & Total \\
\hline Number of samples collected & 50 & 250 & 120 & 60 & 480 \\
Number of samples positive & 5 & 5 & 5 & 2 & 14 \\
Prevalence (\%) & 10 & 0.8 & 4.1 & 3.3 & 2.9 \\
\hline
\end{tabular}

$(p<0.05 ; p=0.0036)$

Table-2. Sex distribution of positivity for antibodies to the avian influenza (H5 subtype virus in village chickens tested across four local government areas in Kaduna State, Nigeria

\begin{tabular}{lccccc}
\hline Sex & \multicolumn{3}{c}{ No. of positive samples in each local government area } & \multicolumn{2}{c}{ Total positive } \\
& J aba & J emma'a & Kaura & Zango Kataf & \\
\hline Males $(n=127)$ & $15(1)$ & $60(2)$ & $30(0)$ & $20(0)$ & $3(2.36)$ \\
Females $(n=353)$ & $35(4)$ & $190(0)$ & $90(5)$ & $38(2)$ & $11(3.12)$ \\
\hline
\end{tabular}

Table-3. Association between positivity of birds for $\mathrm{H} 5 \mathrm{Al}$ antibodies to keeping of pigs and water birds

\begin{tabular}{lcccccc}
\hline Type of animals & Households that keep & $\begin{array}{c}\text { Households thathad } \\
\text { positive birds }\end{array}$ & $\begin{array}{c}\text { Households thathad } \\
\text { negative birds }\end{array}$ & OR (95\% CI) & P value \\
\hline Water birds & 46 & 6 & 8 & $3.49(1.146-10.61)$ & 0.0203 \\
Pigs & 125 & 7 & 7 & $0.9(0.3108-2.695)$ & 0.8723 \\
\hline
\end{tabular}

and Jos where outbreaks occurred.

The State falls within latitude $09^{\circ} 10^{\prime}$ and $11^{\circ}$ $30 \mathrm{~N}$ and longitude $06^{\circ} 10$ and $09^{\circ} \mathrm{E}$ in the Northern Guinea Savannah zone. The area is characterized by three climatic seasons which consists of the cold dry season (November-February), hot-dry season (March -April) and the wet/rainy season (May-October) [6]. The Kagoro forest is located in Kaura local government [7] while Jemma'a local government area has a waterfall and the Nimiba forest reserve which covers about 2,282.4 heaters [8]. The state has a bird population of about 1.5 million comprising of both exotic and village chickens [9].

A total of four hundred and eighty (480) blood samples of village chickens were randomly collected from villages in the four local government areas (Zangon Kataf, Kaura, Jaba and Jema'a) in Kaduna State. A proportionate sampling technique was used to obtain samples from the local government areas. Ten villages were sampled in Jaba local government area while 25, 12 and 6 villages were sampled in Jemma'a, Kaura and Zangon Kataf local government areas respectively. Villages and households sampled were selected based on simple random sampling techniques. Ten [10] samples were collected in each village ( 2 samples per household). All birds sampled were adults comprising of 127 males and 480 females. Serum was separated by centrifugation at $447.2 \mathrm{~g}$ for 5 minutes [10] and stored at $-20^{\circ} \mathrm{C}$ until used. Avian Influenza (H5N2) antigen was obtained from the
Avian influenza and NewCastle disease reference Laboratory, Padova Italy.

One percent suspension of chicken red blood cell (RBC) was prepared for use as the indicator in the haemagglution (HA) and haemagglutination inhibition (HI) test which were performed as described and recommended by the office internationale des epizootics [11]. Serum samples with titres greater than or equal to $1 / 16\left(4 \log _{2}\right)$ were considered positive [11].

Households from where samples were collected where asked if they kept water birds (geese or ducks) or pigs.

Data obtained where expressed in tables. Chi Square or Fisher's exact test was used where appropriate to determine association with the aid of SPSS version 17.0. Values of $p<0.05$ were considered significant.

\section{Results}

Results obtained showed an overall seroprevalence of $2.9 \%$ with an individual seroprevalence of $10 \%$, $0.8 \%, 4.1 \%$ and $3.3 \%$ in Jaba, Jemma'a, Kaura and Zango Kataf local government areas respectively. The highest seroprevalence was found in Jaba LGA (10\%) and the lowest in Jemma'a LGA $(0.8 \%)$ (Table 1$)$. Only $3(2.36 \%)$ of the 127 cocks (males) and $11(3.12 \%)$ out of the 353 hens (females) sampled were positive for the avian influenza (H5 subtype) antibodies (Table 2). There was no association between keeping of pigs and presence of AI antibodies; however, there was a 
significant association between presence of AI antibodies and keeping of water fowl (Table 3 ).

\section{Discussion}

Local chickens are rarely vaccinated [12] and chickens are rarely vaccinated against avian influenza in Nigeria. The presence of avian influenza virus (H5 subtype) antibodies in the village chickens is therefore suggestive of natural exposure of the birds to the virus. Alam et al. [13]; Wakawa et al. [14]; Biswas et al. [15]; Trenvennec et al., [16] in different parts of the world have also reported detecting avian influenza (H5 subtype) antibodies in village chickens, though the prevalence obtained in the present study was lower. This may be because the present study was conducted in an area where outbreak of the disease has not been previously reported. The presence of antibodies in apparently healthy local chickens without any clinical sign may be an indication that they are incubating the organism or they are carriers. Reports have also shown that some village chickens possess the B21 haplotype in the major histocompatibility complex (MHC) class I molecule which makes them resistant to highly pathogenic avian influenza (HPAI) [17]. Also previous exposure of chickens to low pathogenic avian influenza (LPAI) viruses such as H9N2 virus has been shown to modulate the lethality of the infection by $\mathrm{H} 5$ virus subtype and provides partial protection against lethal challenges. This therefore, reduces the clinical manifestation and detectibility of HPAI infection, facilitating the spread of the virus [18]. Transportation of live poultry and poultry products along highways have been implicated in the potential HPAI spread along the road network if infected birds are transported $[19,20]$. Also intense traffic of people in the vicinity of highways and commercial exchanges of live birds among the residents may increase the risk of spread of the disease through the movement of infected materials and fomites $[4,20]$. This may have contributed to the presence of avian influenza antibodies among these birds as infected birds were reported to be transported across these highway during the 2006-2008 avian influenza outbreak between Jos and Abuja where avian influenza outbreaks where reported [4]. Also the presence of forest and water bodies around some of these local government areas e.g Kaura and Jemma,a may have brought the village chickens into contact with wild birds when scavenging.

Pigs play a crucial role in influenza ecology and epidemiology, primarily because of their dual susceptibility to human and avian viruses [21]. Pigs have been proposed to be a "mixing vessel" in the generation of re-assorted strains [22]. There was no association between keeping of pigs and positivity of the birds for avian influenza. However, there was an association between keeping of water fowl (duck and geese) and presence of the antibody. Ducks and geese can play a role as reservoir for avian influenza and source of outbreaks [23]. They can become infected without succumbing to disease [24], they excrete viruses into the environment and contribute to virus persistence and spread [24,25] they also sustain different viral populations allowing opportunity for reassortment [26].

\section{Conclusions and Recommendation}

The presence of avian influenza (H5 subtype) antibodies in village chickens, indicates they were exposed to the virus and the virus may be circulating among apparently healthy village chickens. This poses a serious public health threat because of the frequent and close contact between them and members of the household especially during feeding, and processing (slaughtering and eviscerating) of these birds. These birds may act as reservoir of the virus and might maintain and spread the virus to commercial poultry. A virological survey should be carried out to ascertain the presence of the virus in the village chickens and in areas where AI outbreaks were not reported so that they don't serve as reservoirs and source of spread of the disease.

\section{Author's contributions}

GVT, AI, JK. and OEC conceived and designed the study. GVT, NEO, HSE and MNA implemented the study design including field survey and sampling. GVT, NEO analyzed the samples and data. All author participated in drafting and revision of the manuscript. All authors read and approved the final manuscript.

\section{Acknowledgments}

We are grateful to Ilaria Capua and Matteo of the Avian Influenza and Newcastle Disease Laboratory, Podova, Italy for supplying the antigen (H5N2) and control sera. The staff of the Nutrition Laboratory of the Department of Veterinary Surgery and Medicine, Ahmadu Bello University, Zaria for their assistance during the running of the samples.

\section{Competing interests}

Authors declares that they have no conflict of interest.

\section{References}

1. Adene DF, Oguntade AE (2006). The structure 
andimportance of the commercial and rural based poultry industry in Nigeria. Nigerian Poultry Sector Report, FAO (Rome) study. http://www. fao. org/docs/ eims/ upload//214281/ReviewNigeria.

2. Capua, I. and Marangon, S. (2007). The use of vaccination to combat multiple introductions of notifiable avian influenza viruses of the $\mathrm{H} 5$ and $\mathrm{H} 7$ subtypes between 2000 and 2006 in Italy. Vaccine, $\mathbf{2 5}$ (27):4987-4995.

3. Tiensin, T., Chaitaweesub, P., Songserm, T., Chaisingh, A., Hoonsuwan, W., Buranathai, C., Parakamawongsa, T., Premashthira, S., Amonsin, A. Gilbert, M., Nielen, M. and Stegeman, A. (2005). Highly pathogenic avian influenza H5N1, Thailand, 2004. Emerging Infectious Disease, 11(11): 16641672.

4. Fasina, F.O., Bisschop, S.P., Joannis, T.M., Lombin, L.H. and Abolnik, C. (2008). Molecular characterization and epidemiology of the highly pathogenic avian influenza H5N1 in Nigeria. Epidemiology and Infection, 17: 1-8.

5. Fasina, F.O., Rivas, A.L., Bisschop, S.P.R., Stegeman, A.J., Hernandez, J.A. (2011). Identification of risk factors associated with highly pathogenic avian influenza $\mathrm{H} 5 \mathrm{~N} 1$ virus infection in poultry farms, in Nigeria during the epidemic of 2006-2007. Preventive Veterinary Medicine, 98: 204-208.

6. Ayo, J.O., Oladele, S.B., Ngem, S., Fayomi, A. and Afolayan, S.B. (1999). Diurnal fluctuations in rectal temperature of the Red Sokoto goat during the harmattan season. Research in Veterinary Science, 66: 7-9.

7. Ati, O.F., Sheyin, T., Abbas, I. and Mohammed, S. (2010). Assessing changes in Kagoro forest, Kaduna State Nigeria using remote sensing and GIS. Research Journal of Applied Science, Engineering and Technology, 2(2): 121-132.

8. Samndi, M.A., Raji, B.A. and Kparmwang, T. (2006). Long term effects of fast growing Tree species (ectona grandis linn. F.) on the distribution of pedogenic forms of iron and aluminium in some soils of southern Guienea savannah of Nigeria. Savannah Journal of Agriculture, 1(1): 39-45.

9. Colle, J-R., Duguid, J.P., Fraser, A.G. and Marmion, BP. (1982). Practical Medical Microbiology $13^{\text {th }}$ Ed. Mackie and Mccartney, London, Churchill Livingstone Pp 37-39.

10. KDSG (2007). Data on Estimated annual animal population and fish Production in: Investment Opportunities . Kaduna State Government. Pp16.

11. OIE, (2008). Manual of diagnostic tests and vaccines for terrestrial animals. www.oie:int/manual.Intnl.8/ 02/2011 8:15pm.

12. Dipeolu, M.A., Kenipe, O.M and Gbadamosi, A.I. (1998). Chick mortality in indigenous chickens under free range system in Abeokuta, Nigeria. Veterinary Journal, 19: 5-11.

13. Alam, J., Koike, L., Gasuddin, M. and Rahman, M.M.
(2003). Seroprevalence of poultry disease in native chickens in Bangladesh (abstract). Bangladesh Society for Veterinary Education and Research (BSVER). Bangladesh Agriculture University Mymensingh, Publication no. 24.p.26.

14. Wakawa, A.M., Abdu, P.A., Umoh, J.U., Lawal, S and Miko, R.B. (2009). Serological evidence of mixed infections with avian influenza and NewCastle disease in village chickens in Jigawa State, Nigeria. VeterinariskiArhiv, 79:151-155.

15. Biswas, P.K., Barua, H., Uddin, G.M.N., Biswas, D., Ahad, A. and Debnath, N.C. (2009). Serosurvey of five viruses in chickens on small holdings in Bangladesh. Preventive Veterinary Medicine, 88: 6771.

16. Trenvennec, K., Chevalier, V., Grosbois, V., Garacia, J.M., Thu, H.H., Berthouly-Salazar, C., Peiris, J.S.M. and Roger, F. (2011). Looking for avian influenza in remote areas: a case study in Northern Vietnam. Acta Tropica, 120(3): 160-166.

17. Boonyanuwat, K., Thummabutra, S., Sookmanee, N., Vatechavalkhu, V. and Siripholvat, V. (2006). Influence of major histocompatibility complex class 1 haplotypes on avian influenza virus disease traits in Thai indigenous chickens. Animal Science Journal, 77: 285-289.

18. Khalenkov, A., Perk, S., Pashin, A., Golender, N. and Webster, R.G. (2009). Modulation of the severity of highly pathogenic H5N1 influenza in chickens previously inoculated with Israeli H9N2 influenza viruses. Virology, 383(1): 32-38.

19. Paul, M., Tavornpanich, S., Abrial, D., Gasqui, P., Charras-Garido, M., Thanapongtham, W., Xiao, X., Gilbert, M., Roger, F. and Ducrot, C. (2010). Anthropogenic factors and the risk of highly pathogenic avian influenza H5N1: Prospects from a spatial-based model. Veterinary Research, 41.

20. Paul, M., Wongnarkpet, S., Gasqui, P., Poolkhet, C., Thongratsakul, S., Ducrot, C. And Roger, F. (2011). Risk factors for highly pathogenic avian influenza (HPAI) H5N1 infection in backyard chicken farms, Thialkand. Acta Tropica, 118: 209-216.

21. Kalthoff, D., Globig, A. and Beer, M. (2010). (Highly pathogenic) avian influenza a a zoonotic agent. Veterinary Microbiology, 140; 237-245.

22. Ludwig, S., Stitz, L., Planz, O., Van, H., Fitch, W.M.and Scholtissek, C. (1995). European swine virus as a possible source for the next influenza pandemic? Virology. 212:555-561.

23. Yee, K. S., Carpenter, T. E. and Cardona, C. J. (2009). Epidemiology of H5N1 avian influenza. Comparative Immunology, Microbiology and Infectious Diseases, 32(4): 325-340.

24. Shortridge, K. F., Zhou, N. N. ,Guan, Y. , Gao, P., Ito, T., Kawaoka, Y., Kodihalli, S., Krauss, S., Markwell, D., Murti, K. G., Norwood, M., Senne, D., Sims, L., Takada, A. and Webster, R. G. (1998). Characterization of avian $\mathrm{H} 5 \mathrm{~N} 1$ influenza viruses from 
poultry in Hong Kong. Virology 252 (2):331-42.

25. Hulse-Post, D. J., Sturm-Ramirez, K. M. , Humberd, J., Seiler, P., Govorkova, E. A., Krauss, S., Scholtissek, C., Puthavathana, P., Buranathai, C., Nguyen, T. D., Long, H. T., Naipospos, T. S., Chen, H., Ellis, T. M., Guan, Y., Peiris, J. S. and Webster, R. G. (2005) Role of domestic ducks in the propagation and biological evolution of highly pathogenic $\mathrm{H} 5 \mathrm{~N} 1$ influenza viruses in Asia. Proceedings of National Academy of Science, U S A, 102 (30):10682-7.

26. Chen, H., Deng, G., Li, Z., Tian, G., Li, Y., Jiao, P., Zhang, L., Liu, Z., Webster, R. G. and Yu, K. (2004). The evolution of H5N1 influenza viruses in ducks in southern China. Proceedings of the National Academy of Science U S A, 101 (28):10452-7.

\footnotetext{
$* * * * * * * *$
} 